\title{
Study of Technological Knowledge Perception on Pest Management and Agribusiness Activities in Bangladesh
}

\author{
Mohammad Amir Hossain Mollah ${ }^{1}$, Abdul Jabber Hawlader ${ }^{2}$, Md Razzab Ali ${ }^{3}$, Razia Khatun ${ }^{4}$, \\ Shamim Ahmed ${ }^{4}$, Mohammad Showkat Mahmud ${ }^{4}$, Md. Amirul Hasan ${ }^{4, *}$ \\ ${ }^{1}$ Development Technical Consultants Pvt. Ltd. Dhaka, Bangladesh \\ ${ }^{2}$ Department of Zoology, Jahangirnagar University, Savar, Dhaka, Bangladesh \\ ${ }^{3}$ Department of Entomology, Sher-e-Bangla Agricultural University, Dhaka, Bangladesh \\ ${ }^{4}$ Bangladesh Livestock Research Institute, Savar, Dhaka, Bangladesh
}

Copyright $(\mathrm{O} 2018$ by authors, all rights reserved. Authors agree that this article remains permanently open access under the terms of the Creative Commons Attribution License 4.0 International License

\begin{abstract}
The field survey was conducted among the farmers, researchers, extensionists and agribusiness personnel to assess their knowledge about National Agricultural Research System (NARS) recommended technologies on pest's management, Agribusiness activities and their economic impact in Bangladesh. The survey was conducted in 16 Upazilas (2 Upazilas from each district) of purposively selected eight (8) districts based on agricultural project activities, potential of major crop groups and potential system through a standard pre-tested questionnaire. From the field survey, it was understood that only a few number of NARS recommended Technologies were available at field level regarding pest management and Agribusiness activities in Bangladesh having more than 300 NARS recommended technologies. There was also a big knowledge gap among researchers and other respondents. Considering all technological categories, perceptions of researchers on NARS Technological Knowledge were much higher than farmers, extensionists and agribusiness personnel. There was also a big Knowledge gap between project intervention districts than less or zero project intervention districts. It was observed that most of the respondents were very much aware about the rice based technologies than other crops. Most of the poor farmers especially small scale farmers were interested to use cheap, easy handling and locally available technology for their crop pest management in storage and field level. From the results of the field survey, it was evident that majority of the farmers use different types of containers for storing their rice using different types of plant parts and fumigants for the safe storage of their rice grains.
\end{abstract}

Keywords Technological Knowledge, Pre-and post-harvest, Agricultural pest, Economic Impact, Bangladesh

\section{Introduction}

Agricultural production includes activities starting from land selection for sowing seeds in the field to post harvest activities leading to reach the maximum profitable market and other uses through few dozens of major steps including crop protection in the field during storage. Destructive insect pests and diseases hamper crop production in Bangladesh to a great extent. Various risks and natural disasters also cause serious damage. The climate of Bangladesh is warm and humid which favors development and growth of various pests and diseases. Pests such as insects, mites, nematodes, weeds, vertebrate pests and plant diseases cause regular annual losses to crops. Besides, crop wastes and losses during post-harvest operations and pre-marketing and marketing stages are also significantly important. The economy of Bangladesh is vitally dependent on agriculture, which supports the vast majority of her population, and 7.34 percent of total exports (2005-2006) and employing 52 percent of the total labor force [3]. Rapid increase the use of high yielding rice varieties in the flood free winter season, contributed to the near self-sufficiency in food production in the early 1990s, after many years of severe food deficits. In recent years, there has been a notable increase in the production of fruits, vegetables, pulses, oilseeds, and spice crops, which have developed a demand-driven market in the country and also for some exports. The research team [1] in collaboration 
with the Department of Agricultural Extension (DAE) of the Government of Bangladesh have estimated that about $10-15 \%$ of our potential crops are lost every year by the attack of insect pests and diseases. However during the time of pest outbreaks, which are frequent, these losses may be huge. As for example, Rice his pa outbreak in 1985 severely damaged rice crops of about 707,600 hectares. The yield loss of Boro rice from $36.5 \%$ to $62.5 \%$ due to rice hispa out break that reported by Karim [9].

The fact that loss in yield of crops due to pests and diseases related to various factors such as crop variety, climate and environment, kinds of pests and diseases, age of the crop, time and degree of infestations, soil nutrition, crop management etc. Thus an appraisal of crop loss requires data base information from different sources and for long period of time. Sound methodologies or suitable models for assessment of losses are yet to be developed for many of the pests and diseases in most of the crops. That's why; progress in the research of crop loss assessment has been slow even in the developed countries.

Presently some scattered studies have been initiated to assess crop losses, particularly on rice. However, no systematic and scientific approach has yet been taken to assess these losses on different crops over a period of time. Most of the data available are based mainly on experiments conducted at different research stations and Universities. Most of the data on crop losses have been derived from indirect sources i.e. yield of crops protected by application of pesticides vis-a-vis untreated crops damaged by pests and diseases. In most cases, accuracy of yield reduction estimates was limited due to the quantity and quality of data available. In some crops particularly in vegetables, fruits and oilseeds, information on crop losses are very scanty and inadequate. Also, data on crop losses from different regions of Bangladesh are not available. That is why, it has been a difficult task to compile a reliable annual crop loss estimation for any crops. There is no official information in Bangladesh regarding extend of post-harvest losses in vegetables due to lack of technological knowledge. Knowledge about the present post-harvest activities was found to be practiced at a very limited level [1]. Usually sun-dried and wind dried operations are very common for agricultural produces and sorting and grading are practiced before marketing following the indigenous technology. It was observed that a substantial portion of the harvest is wasted in the region annually due to improper harvesting and post-harvest practices, diseases, lack of facilities and technology to extend their storage life, which cause heavy losses in revenue to the growers, wholesalers, retailers, exporters and inconvenience to the consumers and lowers export potential of these commodities.

The problems recorded in the application of post-harvest practices are: lack of adequate knowledge, space for assembling, sorting, grading and packaging; poor post-harvest technology, inadequate transportation and lack of storage facility/processing center. The farmers are practicing post-harvest activities with traditional knowledge of simple sorting and grading or washing the produces. The traders usually do not encourage any post-harvest operations despite their normal complain on the quality of the produce. Agricultural production has been highly susceptible to attack pests and diseases. In their defense, farmers have begun to use more pesticides to prevent crop losses from pest attack. Pesticide use in Bangladesh negligible until the 1960, has recorded a dramatic increase over the past five decades. The researcher [14] analyzed the trends of different determinants of pesticide used in Bangladesh of over a 33 year period (1977-2009) and found that pesticide use significantly $(\mathrm{p}<0.01)$ grew at an alarming rate of $10 \%$ per year where corresponding major crops yield has been minimal $(<1.0 \%$ per year). The research group[13] conducted a survey about pesticide used in farmland during 1997-2008 showed that in 1997 the use of pesticides in Bangladesh was more than 8000 tons; it doubled to 16000 tons in 2000, and it increased to nearly 20000 tons in 2005 and it rose up to 48690 tons in 2008. Though pesticide use viewed as an economic, labor-saving and efficient tool for pest management and increase crop production [6] but emergence of pest resistance to pesticides is one of the major negative aspects and for this reasons widely use of pesticides employed harmful effects on environmental health

Post-harvest research contributes to sustainability by finding alternatives to chemicals, which have polluting effects on the environment, and are hazardous for human health. Thus alternative pest control mechanisms for grain storage reduce the need for pesticides, which reduces pollution, minimizes accidents with pollutants, and also lowers pesticide residues in food consumed by humans. Value adding opportunities that enhance the value of key commodities would also increase income generation for improving welfare and providing farmers with the financial resources for investment in resource enhancing technologies. As the significant contribution of post-harvest research to CGIAR goals such as poverty reduction, food security and sustainability becomes clear, and in the light of high rates of return, the much skewed allocation of funds to production versus post-harvest topics cannot be justified. It would thus be desirable to reexamine current funding priorities and to allocate a larger proportion of resources to the post-harvest area. The post-harvest research contributes to food security and health in several ways which was pointed out by [6]. Improved storage technologies, such as biological pest control or controlled atmosphere storage reduce post-harvest food losses. Reducing losses increases the amount of food available for consumption. The long-term goals of post-harvest research to improve product availability, to maintain product quality and to improve economics for producers. Progress is being made on many 
fronts on factors which will improve postharvest quality adopting new postharvest and pest management technologies. The factors positively influencing aspirations were found to be higher annual farm income and education levels.

\section{Objective of the Field Survey Study}

In view of the above facts the study was conducted with the following specific objectives:

- Critical analysis of the existing technological knowledge and level of adoption of pest management practices of crops;

- To identify the gaps between existing agricultural pest management systemand expectations from the perspective of stakeholders.

- To recommend the output of the study to the concerned policy makers of Government.

\section{Materials and Methods}

\subsection{Locale of the Study}

Field survey was conducted in the eight (8) districts namely Bogra, Pabna, Nilphamari, Gaibandha, Kurigram, Dinajpur, Panchagar and Netrakona of Bangladesh and it was purposively selected based on agricultural project activities, potential of major crop groups and potential system. The control district was purposively selected based on zero projects activities, and single crop potential. The field data were collected from four categories of respondents such as Farmers-who has land of more than one crops, Extensionists, Researches, and Agribusiness men through face to face interviews.

\subsection{Development of the Questionnaire and Collection of Data}

The main instrument for the data collection was structured questionnaires. The questionnaire was pre-tested in the sample location and finalized with due care to be able to the objectives of the research work as well as the consistency with the scope of work. Direct personal interview approach was adopted for collection of data. Necessary data were collected based on guideline, questionnaire and checklist of the questionnaire following he techniques, procedures, and demonstration of the field pre-testing.

\subsection{Sampling}

The number of respondents interviewed was 480 representing 320 farmers, 48 Researcher, 64 Extensionist,
48 Agri-business man in eight districts of Bangladesh. In addition, eight FGDs (Focus Group Discussions) and some Key Informant Interviews (KII) were administered with different stakeholders.

\subsection{Data Origination}

The sample of the proposed study for generating the field data was structured in a manner so as to cover desired predetermined respondents categories in all the 16 upazilas of 8 districts that has land of more than one crops. The sample size was determined in such a way so as to provide a reliable collection of data systematically, indicative of the technological knowledge on pest management of agricultural production, processing and storing practices prevailing in those 16 upazilas prior to conduct the study. Taking all these factors into account, the sample size was determined by using suitable sampling procedure, a statistically valid proportion of the respondents were selected randomly. The filled-in questionnaires were considered as the source of raw data and for effective and accurate analysis and quality output generation.

\subsection{Data Analysis}

All the necessary analysis was done using Excel and SPSS. For the analysis of the study data, descriptive statistics such as percent, sum and average etc. was used to describe some characteristics. Correlation co-efficient, and bar diagram analysis was used according to the objectives.

\section{Results and Discussion}

Interviews were conducted in 16 randomly selected Upazilas of 8 districts in Bangladesh. Out of 300 NARS (National Agricultural Research System) technologies, so far 36 technologies were found to cover the pest management and agribusiness categories.

\subsection{Farmers' Knowledge on Pest Management Technology}

The pest management activities consisted of three-major categories that were rouging, processing including drying, cleaning and grading and storage environment etc. Significant variations were observed in the perceptions of farmer's pest management activities (Table 1). In case of cereal crops, the number of known pest management activities ranged from $29.11 \%-73.43 \%$, where highest number were observed in processing and lowest number were observed in rouging activity. In case of vegetables/fruits sub-sector, the number of known pest management activities ranged from $13.44 \%-48.60 \%$ highest number was observed in processing and lowest number was observed in rouging. More or less similar trends observed in pulse 
(11.44\%-32.75\%) and spices (5.33\%-29.75\%). Sharp and significant variations were observed among three categories of pest management activities for rouging, processing, and storage environment, respectively in respect of all types of crops. This is being for the training through extension services providers and development projects regarding processing of crops but less on roughing of pest management as it is highly technical terms that needs certain level of farmers' educational knowledge but our farmer's are usually illiterate or minimum educational knowledge. This finding was supported by Manjunatha ET el., [11] statement where greater communication of experiences is required if farmers' aspirations are to be raised regarding the outcomes of adopting new pest management technologies. The factors positively influencing aspirations were found to be higher annual farm income and education levels. New technologies such as microwave processing to improve quality should be better used in future. Researcher [14] was carried out survey to investigate farmers' perceptions of bean pest problems to complement observations made in the field; to gain an understanding of the extent of farmers' knowledge of the pests; to ascertain information on farmers' pest control methods; and to identify knowledge gaps which were in accordance of the present study.

\subsection{Agribusiness Activities}

The agribusiness activities data were collected on the above three categories of agribusiness activities for four major crop groups (Table 1).The crop wise distribution of the data showed that the cereal crops were marked the highest average being $6.77(23.47 \%)$ and the lowest being in case of spices $0.74(8.89 \%)$ under category of impact on agribusiness activities.

The results depicted significant variations in the perceptions of farmer's on the agribusiness activities viz. storing, transportation and marketing available in the field of different crops. In case of cereal crops, the number of known agribusiness activities ranged from $20.33 \%-27 \%$, where highest number were observed in sorting $(27 \%)$ and lowest number observed in marketing $(20.33 \%)$. In case of vegetables/fruits agribusiness activities ranged from $22.59 \%-44.87 \%$ where highest number were observed in transportation and lowest number observed in storing. In this field survey, more or less similar trends of results of vegetables/fruits in case of pulse (24.22\%-30.40\%) and spices $(7.50 \%-10.40 \%)$. Sharp and significant variations were observed among three categories of agribusiness activities for storing, marketing and transportation respectively in respect of all types of crops.

Proper management of post-harvest handling including agro processing is one of the best alternatives to reduce this post-harvest loss and to accelerate their export due to lack of storage facilities, poor transport and marketing system, most of the vegetables especially which are very perishable such as tomato, leafy vegetables, palwal etc. suffer heavy spoilage and wastage during different post-harvest operations including marketing $[8,13]$ reported that post-harvest losses of vegetables in Bangladesh could reach as high as $43 \%$. Post-harvest losses during handling and distribution may go upto20-25\%in case of perishable vegetables such as tomatoes in the SAARC countries [4].

Table 1. Farmers' perception of technological knowledge on pre and post harvest agricultural pests and their economic impacts in Bangladesh

\begin{tabular}{|c|c|c|c|c|c|c|c|c|c|c|}
\hline \multirow{3}{*}{$\begin{array}{l}\text { Technological } \\
\text { Category }\end{array}$} & \multicolumn{10}{|c|}{ Crop wise Technological knowledge } \\
\hline & \multicolumn{2}{|c|}{ Cereal } & \multicolumn{2}{|c|}{ Vegetable/fruit } & \multicolumn{2}{|c|}{ Pulse } & \multicolumn{2}{|c|}{ Spices } & \multicolumn{2}{|c|}{ Total } \\
\hline & $\begin{array}{l}\text { *NARS } \\
\text { Tech. } \\
\text { (No.) }\end{array}$ & $\begin{array}{c}\text { Response } \\
(\%)\end{array}$ & $\begin{array}{l}\text { NARS } \\
\text { Tech. } \\
\text { (No.) }\end{array}$ & $\begin{array}{c}\text { Response } \\
(\%)\end{array}$ & $\begin{array}{l}\text { NARS } \\
\text { Tech. } \\
\text { (No.) }\end{array}$ & $\begin{array}{c}\text { Response } \\
(\%)\end{array}$ & $\begin{array}{c}\text { NARS } \\
\text { Tech } \\
\text { (No) }\end{array}$ & $\begin{array}{c}\text { Response } \\
(\%)\end{array}$ & $\begin{array}{c}\text { NARS } \\
\text { Tech. } \\
\text { No) }\end{array}$ & $\begin{array}{c}\text { Response } \\
(\%)\end{array}$ \\
\hline \multicolumn{11}{|c|}{ 1. Pest Management Activities } \\
\hline Rouging & 9 & $\begin{array}{l}29.11 \\
(2.62)\end{array}$ & 9 & $\begin{array}{l}13.44 \\
(1.21)\end{array}$ & 9 & $\begin{array}{l}11.44 \\
(1.03)\end{array}$ & 9 & $\begin{array}{c}5.33 \\
(0.48) \\
\end{array}$ & 36 & $\begin{array}{l}14.83 \\
(5.34)\end{array}$ \\
\hline Processing & 6 & $\begin{array}{l}73.83 \\
(4.43)\end{array}$ & 5 & $\begin{array}{l}48.60 \\
(2.43)\end{array}$ & 9 & $\begin{array}{l}21.11 \\
(1.90)\end{array}$ & 7 & $\begin{array}{l}18.14 \\
(1.27)\end{array}$ & 27 & $\begin{array}{c}37.15 \\
(10.03)\end{array}$ \\
\hline $\begin{array}{c}\text { Storage } \\
\text { environment }\end{array}$ & 10 & $\begin{array}{l}35.00 \\
(3.5)\end{array}$ & 4 & $\begin{array}{l}45.00 \\
(1.80)\end{array}$ & 4 & $\begin{array}{l}32.75 \\
(1.31)\end{array}$ & 4 & $\begin{array}{l}29.75 \\
(1.19) \\
\end{array}$ & 22 & $\begin{array}{l}35.45 \\
(7.8) \\
\end{array}$ \\
\hline Average total & 8.33 & $\begin{array}{l}45.98 \\
(3.52) \\
\end{array}$ & 6 & $\begin{array}{l}35.68 \\
(1.82) \\
\end{array}$ & 7.33 & $\begin{array}{l}21.77 \\
(1.41) \\
\end{array}$ & 6.67 & $\begin{array}{l}17.74 \\
(0.98) \\
\end{array}$ & 28.33 & $\begin{array}{l}29.14 \\
(7.72) \\
\end{array}$ \\
\hline \multicolumn{11}{|c|}{ 2. Agribusiness Activities } \\
\hline Storing & 8 & $\begin{array}{l}27.00 \\
(2.16) \\
\end{array}$ & 5 & $\begin{array}{l}30.40 \\
(1.52)\end{array}$ & 8 & $\begin{array}{l}11.00 \\
(0.88) \\
\end{array}$ & 5 & $\begin{array}{l}10.40 \\
(0.52) \\
\end{array}$ & 26 & $\begin{array}{l}19.54 \\
(5.08)\end{array}$ \\
\hline Transportation & 12 & $\begin{array}{l}23.08 \\
(2.77)\end{array}$ & 12 & $\begin{array}{l}25.17 \\
(3.02)\end{array}$ & 12 & $\begin{array}{l}10.33 \\
(1.24)\end{array}$ & 12 & $\begin{array}{c}7.50 \\
(0.90)\end{array}$ & 48 & $\begin{array}{l}16.56 \\
(7.95)\end{array}$ \\
\hline Marketing & 9 & $\begin{array}{l}20.33 \\
(1.83)\end{array}$ & 9 & $\begin{array}{l}24.22 \\
(2.18)\end{array}$ & 9 & $\begin{array}{l}16.00 \\
(1.44)\end{array}$ & 9 & $\begin{array}{c}8.78 \\
(0.79)\end{array}$ & 36 & $\begin{array}{l}17.36 \\
(6.25)\end{array}$ \\
\hline Average total & 9.67 & $\begin{array}{l}23.47 \\
(6.77)\end{array}$ & 8.67 & $\begin{array}{l}26.60 \\
(2.24)\end{array}$ & 9.67 & $\begin{array}{l}12.44 \\
(1.19)\end{array}$ & 8.67 & $\begin{array}{c}8.89 \\
(0.74)\end{array}$ & 36.67 & $\begin{array}{l}17.82 \\
(6.43)\end{array}$ \\
\hline
\end{tabular}

The number within the parenthesis indicates the number of technologies being responded by the farmer. "The number of NARS recognized available technologies 


\subsection{Extensionists' Knowledge on Technology}

The results of crop wise available technological knowledge of agricultural extensionist including their major categories and sub-categories have been discussed under the following sub-headings.

\subsubsection{Pest Management Activities}

The pest management activities consisted of rouging, processing including drying, cleaning and grading and storage environment etc. the data were collected on the above three categories of pest management activities for 4 major crops group and are illustrated in the Table 2 . Significant variations were observed in the perceptions of extensionist's on regarding pest management activities viz. rouging, processing, and storage environment available in the field of different crops. In case of cereal crops, the number of known pest management activities ranged from $25.44 \%$ $-83.17 \%$, where the highest number was observed in processing and lowest in rouging activity. In case of vegetables/fruits sub-sector, pest management activities ranged from $16.33 \%-47.20 \%$ where the highest number observed in processing and lowest number observed in rouging. More or less similar trends of results in pulse $(11.22 \%-45.75 \%)$ and spices (10.88\%-44.50\%) sub-sectors as observed in the vegetables/fruits sub-sector. Sharp and significant variations were observed among three categories of pest management activities $(25.44 \% ; 71.90 \%$, and $83.17 \%$ activities for rouging, processing, and storage environment, respectively in respect of total number of crops. The research work of $[7,11,15]$ supported the above findings of the study as mentioned in farmers' pest management activities.

\subsubsection{Agribusiness Activities}

The agribusiness activities for four major crop groups are given in the Table 2 . The cereal crops were marked the highest average being $36.55 \%$ and the lowest being in pulse $26.67 \%$. Significant variations were observed in the perceptions of farmer's on the agribusiness activities viz. storing, transportation and marketing available in the field of different crops. In case of cereal crops, the number of known agribusiness activities ranged from $23.08 \%-54.13 \%$, where the highest number were observed in storing and lowest number observed in transportation. In case of vegetables/fruits sub-sector, the number of known agribusiness activities ranged from $25.17 \%-45.80 \%$ s, where the highest number observed in storing and lowest number observed in transportation. More or less similar trends of results in case of pulse (10.33\%-39.13\%) and spices $(7.50 \%-43.20 \%)$ activities. Sharp and significant variations were observed among three categories of agribusiness activities for storing, transportation and marketing of crops, respectively in respect of all types of crops. Total losses of vegetables occurred in India due to inadequate post-harvest handling, transport and storage are estimated at 20-25\%which supported by [10]. Pre- and postharvest treatments applied to vegetables in India to reduce postharvest losses are outlined. Research works $[1,8]$ finding also support the above activities findings as mentioned in farmers' agribusiness activities.

Table 2. Extensionists' perception of technological knowledge on pre and post-harvest management of agricultural pests and their economic impacts in Bangladesh

\begin{tabular}{|c|c|c|c|c|c|c|c|c|c|c|}
\hline \multirow{3}{*}{$\begin{array}{c}\text { Technological } \\
\text { Category }\end{array}$} & \multicolumn{10}{|c|}{ Crop Wise Technological Knowledge } \\
\hline & \multicolumn{2}{|c|}{ Cereal } & \multicolumn{2}{|c|}{ Vegetable/Fruit } & \multicolumn{2}{|c|}{ Pulse } & \multicolumn{2}{|c|}{ Spices } & \multicolumn{2}{|c|}{ Total } \\
\hline & $\begin{array}{c}\text { *NARS } \\
\text { Tech } \\
\text { (No.) } \\
\end{array}$ & $\begin{array}{l}\text { Response } \\
(\%)\end{array}$ & $\begin{array}{c}\text { *NARS } \\
\text { Tech } \\
\text { (No.) } \\
\end{array}$ & $\begin{array}{c}\text { Response } \\
(\%)\end{array}$ & $\begin{array}{c}* \text { NARS } \\
\text { Tech } \\
\text { (No.) }\end{array}$ & $\begin{array}{c}\text { Response } \\
(\%)\end{array}$ & $\begin{array}{c}\text { *NARS } \\
\text { Tech } \\
\text { (No.) } \\
\end{array}$ & $\begin{array}{l}\text { Response } \\
(\%)\end{array}$ & $\begin{array}{l}\text { *NARS } \\
\text { Tech } \\
\text { (No.) } \\
\end{array}$ & $\begin{array}{c}\text { Response } \\
(\%)\end{array}$ \\
\hline \multicolumn{11}{|c|}{ 1. Pest Management Activities } \\
\hline Rouging & 9 & $\begin{array}{l}25.44 \\
(2.23)\end{array}$ & 9 & $\begin{array}{l}16.33 \\
(1.47)\end{array}$ & 9 & $\begin{array}{l}11.22 \\
(1.01)\end{array}$ & 9 & $\begin{array}{l}10.88 \\
(0.98)\end{array}$ & 36 & $\begin{array}{l}15.50 \\
(5.58)\end{array}$ \\
\hline Processing & 6 & $\begin{array}{l}83.17 \\
(4.99)\end{array}$ & 5 & $\begin{array}{l}47.20 \\
(2.36) \\
\end{array}$ & 9 & $\begin{array}{l}41.67 \\
(3.75)\end{array}$ & 7 & $\begin{array}{l}28.42 \\
(1.99)\end{array}$ & 27 & $\begin{array}{c}63.31 \\
(37.52) \\
\end{array}$ \\
\hline $\begin{array}{c}\text { Storage } \\
\text { Environment }\end{array}$ & 10 & $\begin{array}{l}71.90 \\
(7.19)\end{array}$ & 4 & $\begin{array}{l}45.25 \\
(1.81)\end{array}$ & 4 & $\begin{array}{l}45.75 \\
(1.83)\end{array}$ & 4 & $\begin{array}{l}44.50 \\
(1.78)\end{array}$ & 22 & $\begin{array}{c}59.59 \\
(13.11) \\
\end{array}$ \\
\hline Average total & 8.33 & $\begin{array}{l}60.17 \\
(4.80)\end{array}$ & 6 & $\begin{array}{l}36.26 \\
(1.88)\end{array}$ & 7.33 & $\begin{array}{l}32.88 \\
(2.20)\end{array}$ & 6.67 & $\begin{array}{c}27.93 \\
(1.580)\end{array}$ & 28.33 & $\begin{array}{c}46.13 \\
(18.74) \\
\end{array}$ \\
\hline \multicolumn{11}{|c|}{ 2. Agribusiness Activities } \\
\hline Storing & 8 & $\begin{array}{l}54.13 \\
(4.33) \\
\end{array}$ & 5 & $\begin{array}{l}45.80 \\
(2.29) \\
\end{array}$ & 8 & $\begin{array}{l}39.13 \\
(3.13) \\
\end{array}$ & 5 & $\begin{array}{l}43.20 \\
(2.16) \\
\end{array}$ & 26 & $\begin{array}{c}41.15 \\
(10.70)\end{array}$ \\
\hline Transportation & 12 & $\begin{array}{l}23.08 \\
(2.77)\end{array}$ & 12 & $\begin{array}{l}25.17 \\
(3.02)\end{array}$ & 12 & $\begin{array}{l}10.33 \\
(1.24)\end{array}$ & 12 & $\begin{array}{c}7.50 \\
(0.90)\end{array}$ & 48 & $\begin{array}{l}16.56 \\
(7.95)\end{array}$ \\
\hline Marketing & 9 & $\begin{array}{l}32.44 \\
(2.92)\end{array}$ & 9 & $\begin{array}{l}31.33 \\
(2.82) \\
\end{array}$ & 9 & $\begin{array}{l}30.56 \\
(2.75) \\
\end{array}$ & 9 & $\begin{array}{l}29.78 \\
(2.68) \\
\end{array}$ & 36 & $\begin{array}{c}31.11 \\
(11.20)\end{array}$ \\
\hline Average total & 9.67 & $36.55(3.34)$ & 8.67 & $34.10(2.71)$ & 9.67 & $26.67(2.37)$ & 8.66 & $26.82(1.91)$ & 36.67 & $29.60(9.95)$ \\
\hline
\end{tabular}

The number within the parenthesis indicates the number of technologies being responded by the farmer. "The number of NARS recognized available technologies 


\subsection{Researcher Knowledge on Technology}

The results of crop wise available technological knowledge of researcher including their major categories and sub-categories have been discussed under the following sub-headings:

\subsubsection{Pest Management Activities}

The pest management activities consist of three-major categories that are rouging, processing including drying, cleaning and grading and storage environment etc. the data were collected on the above three categories of pest management activities for 4 major crops group and are illustrated in the Table 3.Significant variations were observed in the perceptions of researcher on the NARS recognized technologies/activities regarding pest management activities viz. rouging, processing, and storage environment available in the field of different crops. In case of cereal crops, available recognized activities, the number of known pest management activities ranged from $39.44 \%-89.83 \%$, where the highest number was observed in processing and the lowest number observed in rouging. In case of vegetables/fruits pest management activities ranged from $24.56 \%-88.60 \%$ where the highest number was observed in processing and the lowest number observed in rouging. . The research work of $[9,13,18]$ supports the above finds of the study as mentioned in farmers' pest management activities.

\subsubsection{Agribusiness Activities}

The agribusiness activities data were collected on the three categories for four major crop groups and are given in the Table 3. The cereal and vegetable crops were being marked more or less similar value $59.53 \%$ and $59.56 \%$ respectively regarded highest average value and the lowest being in case of pulse $55.57 \%$. The significant variations were observed in the perceptions of researcher on the agribusiness activities viz. storing, transportation and marketing available in the field of different crops. In case of cereal crops, the number of known agribusiness activities ranged from $48.33 \%-75.75 \%$, where the highest number of activities was observed in respect of storing and the lowest number of activities was observed in marketing activity.

Table-3. Perception of researchers' technological knowledge on pre and post-harvest pest management system and their impact on agribusiness in Bangladesh

\begin{tabular}{|c|c|c|c|c|c|c|c|c|c|c|}
\hline \multirow{3}{*}{$\begin{array}{c}\text { Technological } \\
\text { Category }\end{array}$} & \multicolumn{10}{|c|}{ Crop Wise Technological Knowledge } \\
\hline & \multicolumn{2}{|c|}{ Cereal } & \multicolumn{2}{|c|}{ Vegetable/Fruit } & \multicolumn{2}{|c|}{ Pulse } & \multicolumn{2}{|c|}{ Spices } & \multicolumn{2}{|c|}{ Total } \\
\hline & $\begin{array}{c}\text { *NARS } \\
\text { Tech } \\
\text { (No.) }\end{array}$ & $\begin{array}{c}\text { Response } \\
(\%)\end{array}$ & $\begin{array}{c}\text { *ARS } \\
\text { Tech } \\
\text { (No.) }\end{array}$ & $\begin{array}{c}\text { Response } \\
(\%)\end{array}$ & $\begin{array}{c}\text { *NARS } \\
\text { Tech } \\
\text { (No.) }\end{array}$ & $\begin{array}{l}\text { Response } \\
(\%)\end{array}$ & $\begin{array}{c}\text { *NARS } \\
\text { Tech } \\
\text { (No.) }\end{array}$ & $\begin{array}{c}\text { Response } \\
(\%)\end{array}$ & $\begin{array}{c}\text { *NARS } \\
\text { Tech } \\
\text { (No.) }\end{array}$ & $\begin{array}{c}\text { Response } \\
(\%)\end{array}$ \\
\hline \multicolumn{11}{|c|}{ 1. Pest Management Activities } \\
\hline Rouging & 9 & $\begin{array}{l}39.44 \\
(3.55)\end{array}$ & 9 & $24.56(2.21)$ & 9 & $18.56(1.67)$ & 9 & $19.22(1.73)$ & 36 & $25.36(9.13)$ \\
\hline $\begin{array}{c}\text { Drying, } \\
\text { Cleaning } \\
\text { /Processing }\end{array}$ & 6 & $\begin{array}{l}89.83 \\
(5.39)\end{array}$ & 5 & $88.60(4.43)$ & 9 & $71.44(6.43)$ & 7 & $80.71(5.65)$ & 27 & $81.11(21.90)$ \\
\hline $\begin{array}{c}\text { Storage } \\
\text { Environment }\end{array}$ & 10 & $\begin{array}{l}85.50 \\
(8.55)\end{array}$ & 4 & $86.50(3.46)$ & 4 & $85.50(3.42)$ & 4 & $86.50(3.46)$ & 22 & $85.79(18.87)$ \\
\hline Average total & 8.33 & $\begin{array}{l}71.59 \\
(5.83)\end{array}$ & 6 & $66.55(3.37)$ & 7.33 & $58.50(3.84)$ & 6.67 & $62.14(3.61)$ & 28.33 & $64.09(16.63)$ \\
\hline \multicolumn{11}{|c|}{ 2. Agribusiness Activities } \\
\hline Storing & 8 & $\begin{array}{l}75.75 \\
(6.06) \\
\end{array}$ & 5 & $78.40(3.92)$ & 8 & $72.50(5.80)$ & 5 & $78.40(3.92)$ & 26 & 75.77(19.70) \\
\hline Transportation & 12 & $\begin{array}{l}54.50 \\
(6.54)\end{array}$ & 12 & $54.50(6.54)$ & 12 & $54.50(6.54)$ & 12 & $54.50(6.54)$ & 48 & $54.50(26.16)$ \\
\hline Marketing & 9 & $\begin{array}{l}48.33 \\
(4.35) \\
\end{array}$ & 9 & $45.78(4.12)$ & 9 & $40.00(3.60)$ & 9 & $38.11(3.43)$ & 36 & $43.06(15.50)$ \\
\hline Average total & 9.67 & $\begin{array}{l}59.53 \\
(5.65)\end{array}$ & 8.67 & $59.56(4.86)$ & 7.25 & $55.67(5.31$ & 8.67 & $57.0(4.63)$ & 36.67 & $57.77(20.45)$ \\
\hline
\end{tabular}

The number within the parenthesis indicates the number of technologies being responded by the farmer. ${ }^{*}$ The number of NARS recognized available technologies

In case of vegetables/fruits sub-sector, the number of known agribusiness activities ranged from $45.78 \%-78.40 \%$ agribusiness activities, where the highest number of activities was observed in respect of storing and the lowest number of activities was observed in Marketing. More or less similar trends of results in case of pulse $40 \%-72.50 \%$ and spices $38.11 \%-78.40 \%$, activities. Sharp and significant variations were observed among three categories of agribusiness activities for storing, transportation and marketing of crops, respectively in respect of all types of crops. This is supported by $[1,8,10]$ research works as mentioned detailed under farmers' agribusiness activities. 


\subsection{Agribusiness Personnel Knowledge on Technology}

The results of crop wise available technological knowledge of agribusiness personnel including their major categories and sub-categories have been discussed under the following sub-headings.

\subsubsection{Pest management Activities}

The pest management activities consist of three-major categories that are rouging, processing including drying, cleaning and grading and storage environment etc. the data were collected on the above three categories of pest management activities for 4 major crops group and are illustrated in the Table 4. Significant variations were observed in the perceptions of agribusiness personnel on the NARS recognized technologies/activities regarding pest management activities viz. rouging, processing, and storage environment available in the field of different crops. In case of cereal crops, the percent of known pest management activities ranged from $21.20 \%-83.17 \%$, where the highest number of activities observed in respect of post harvest processing and the lowest number of activities observed in rouging activity. In case of vegetables/fruits sub-sector, the number of known pest management activities ranged from $19.00-90.80 \%$, where the highest number of activities was observed in respect of Post harvest processing and the lowest number of activities was observed in respect of rouging. More or less similar trends of results in case of pulse (19.00, 72.78 , and 82.80 out of $9,9, \& 4$ activities) and spices (15.33, 62.43 , and $73.25 \%$ sub-sectors as observed in the vegetables/fruits sub-sector. Sharp and significant variations were observed among three categories of pest management activities $(19.00,75.74$, and $79.07 \%$ for rouging, processing, and storage environment, respectively) in respect of total number of crops. The research work of $[7,11.15]$ supports the above finds of the study as mentioned in farmers' pest management activities. Considering the total number of pest management activities in percent, the maximum activities (79.07\%) were perceived by the agribusiness personnel in storage environment followed by post harvest processing (75.37\%), while the minimum activities (19.00) in rouging categories.

\subsubsection{Agribusiness Activities}

The agribusiness activities data were collected on the three categories for four major crop groups and are given in the Table 4 . The crop wise distribution of the data showed that the cereal crops were marked the highest average being $54.13 \%$ and the lowest being in case of pulse $39.13 \%$.

Significant variations were observed in the perceptions of farmer's on the agribusiness activities viz. storing, transportation and marketing available in the field of different crops. In case of cereal crops, the number of known agribusiness activities ranged from 82.13-89.44, where the highest number of activities was observed in respect of marketing and the lowest number of activities was observed in respect of transportation activity. In case of vegetables/fruits sub-sector, the number of known agribusiness activities ranged from 66.75-86.20 agribusiness activities, where the highest number of activities was observed in respect of storing and the lowest number of activities was observed in respect of transportation. More or less similar trends of results in case of pulse 67.22-77.38 activities and spices 55.67-83.80 activities. Sharp and significant variations were observed among three categories of agribusiness activities for storing, transportation and marketing of crops, respectively in respect of all types of crops. This is supported by $(1,8,11)$ research work findings as mentioned in farmers' agribusiness activities

Table 4. Agribusiness personnel's perception of technological knowledge on pre and post-harvest management of agricultural pests and their economic impacts in Bangladesh

\begin{tabular}{|c|c|c|c|c|c|c|c|c|c|c|}
\hline \multirow{3}{*}{$\begin{array}{c}\text { Technological } \\
\text { Category }\end{array}$} & \multicolumn{10}{|c|}{ Crop Wise Technological Knowledge } \\
\hline & \multicolumn{2}{|c|}{ Cereal } & \multicolumn{2}{|c|}{ Vegetable/Fruit } & \multicolumn{2}{|c|}{ Pulse } & \multicolumn{2}{|c|}{ Spices } & \multicolumn{2}{|c|}{ Total } \\
\hline & $\begin{array}{c}\text { *NARS } \\
\text { Tech } \\
\text { (No.) }\end{array}$ & $\begin{array}{c}\text { Response } \\
(\%)\end{array}$ & $\begin{array}{c}\text { *NARS } \\
\text { Tech } \\
\text { (No.) }\end{array}$ & $\begin{array}{l}\text { Response } \\
(\%)\end{array}$ & $\begin{array}{c}\text { *NARS } \\
\text { Tech } \\
\text { (No.) }\end{array}$ & $\begin{array}{l}\text { Response } \\
\text { (\%) }\end{array}$ & $\begin{array}{c}* \text { NARS } \\
\text { Tech } \\
\text { (No.) }\end{array}$ & $\begin{array}{l}\text { Response } \\
(\%)\end{array}$ & $\begin{array}{c}* \text { NARS } \\
\text { Tech } \\
\text { (No.) }\end{array}$ & $\begin{array}{l}\text { Response } \\
\text { (\%) }\end{array}$ \\
\hline \multicolumn{11}{|c|}{ 1. Pest Management Activities } \\
\hline Rouging & 9 & $\begin{array}{l}11.77 \\
(1.06)\end{array}$ & 9 & $8.44(0.76)$ & 9 & $6.33(0.57)$ & 9 & $5.11(0.46)$ & 36 & $7.92(2.85)$ \\
\hline PH Processing & 6 & $\begin{array}{l}83.17 \\
(4.99)\end{array}$ & 5 & $90.80(4.54)$ & 9 & $72.78(6.55)$ & 7 & $62.43(4.37)$ & 27 & $75.74(20.45)$ \\
\hline $\begin{array}{c}\text { Storage } \\
\text { Environment }\end{array}$ & 10 & $\begin{array}{l}78.40 \\
(7.84) \\
\end{array}$ & 4 & $77.25(3.09)$ & 4 & $82.80(3.31)$ & 4 & $73.25(2.93)$ & 22 & $79.07(17.39)$ \\
\hline $\begin{array}{c}\text { Average } \\
\text { Total } \\
\end{array}$ & 8.33 & $\begin{array}{l}57.78 \\
(4.63) \\
\end{array}$ & 6 & $58.83(2.80)$ & 7.33 & $53.97(3.48)$ & 6.67 & $46.93(2.59)$ & 28.33 & $54.24(15.36)$ \\
\hline \multicolumn{11}{|c|}{ 2. Agribusiness Activities } \\
\hline Storing & 8 & $\begin{array}{l}82.13 \\
(6.57) \\
\end{array}$ & 5 & $86.20(4.31)$ & 8 & $77.38(6.19)$ & 5 & $83.80(4.19)$ & 26 & $81.77(21.26)$ \\
\hline Transportation & 12 & $\begin{array}{l}76.58 \\
(9.19) \\
\end{array}$ & 12 & $66.75(8.01)$ & 12 & $70.25(8.43)$ & 12 & $67.92(8.15)$ & 48 & $70.38(33.78)$ \\
\hline Marketing & 9 & $\begin{array}{l}89.44 \\
(8.05)\end{array}$ & 9 & $67.22(6.05)$ & 9 & $67.22(6.05)$ & 9 & $55.67(5.01)$ & 36 & $69.89(25.16)$ \\
\hline $\begin{array}{c}\text { Average } \\
\text { Total } \\
\end{array}$ & 9.66 & $\begin{array}{l}82.72 \\
(7.94) \\
\end{array}$ & 8.67 & $73.9(6.12)$ & 9.67 & $71.62(6.89)$ & 8.67 & $69.13(5.78)$ & 36.7 & $74.01(26.73)$ \\
\hline
\end{tabular}

The number within the parenthesis indicates the number of technologies being responded by the farmer. ${ }^{*}$ The number of NARS recognized available technologies 


\section{Pest Management Activities-based Technological Knowledge for All Categories Respondents}

The pest management activities consists the major three categories such as Rouging, Post Harvest Processing for pest management, Storage environment of crops. The data were collected on the above three categories of technological aspects for 4 major crops group and are given in the Table 5.

\subsection{Rouging}

The rouging comprises major categories termed as crop(s) need for rouging, pests need for rouging, and growth stages of crops need for rouging. The data were collected on the above three categories of technological aspects for 4 types of respondents and are given in the Table 5 .

The results depicted significant variations in the perceptions of rouging activities viz. crops, pests, and growth stages of crops need for rouging. In case of researcher, out of 5,7 \& 4 available activities/technologies, the percent of rouging activities ranged from 71.14-94.00, where the highest numbers of activities were observed in growth stages of crops need for rouging with minimal difference with crop (s) need for rouging but lowest was observed in pests need for rouging. In case of extensionist, the percent of rouging activities ranged from 48.71-62.20, where the lowest number of activities was observed similar to researcher in pests need for rouging, whereas highest number of activities was observed in crop(s) need for rouging. In respect of farmers, the percent rouging activities ranged from 23.86-35.00 where highest percent perceived in crop(s) need for rouging and lowest percent (23.86) perceived in pests need for rouging. The similar trends of results in case of agribusiness where highest percent (56.00) perceived in growth stages of crop need for rouging and lowest percent (29.00) perceived in pests need for rouging. Significance variations were observed among these two categories of respondents. The result supported by [15] who was carried out survey to investigate farmers' perceptions of bean pest problems to complement observations made in the field; to gain an understanding of the extent of farmers' knowledge of the pests; to ascertain information on farmers' pest control methods; and to identify knowledge gap.

Considering the total number of rouging about technologies, the maximum activities/technologies (60.50) in percent were perceived by the growth stages of crops need for rouging followed by crop(s) need for rouging (58.55), while the minimum percent (43.18) in pests need for rouging. The respondents wise distribution of the data shown that the researcher marked highest the average being 85.73 and lowest being in case of Farmer's 30.85 under all three categories out of average 5.33 technologies followed by extensionist (56.35) and agribusiness person (43.24).

\subsection{Processing for Pest Management}

The processing for pest management consists of seasonal crops need for drying, cleaning and grading, pests need for drying, cleaning and grading, and crop's agribusiness need for drying, cleaning and grading. The data were collected on the above three categories of post harvest activities for 4 types of respondents. Minimal variations were observed in respect of crops, pests and crop's agribusiness need for drying, cleaning and grading in all three categories of post harvest activities regarding four categories of respondent's viz. researcher, extensionist, farmer, and agribusiness personnel of crops. In case of researcher, out of $11,6, \& 11$ available recognized activities, the percent of researcher post harvest activities about seasonal crops need for drying, cleaning and grading ranged from 64.83-73.09, where the highest number of activities was observed in respect of seasonal crops and the lowest number of technologies was observed in respect of pests need for drying, cleaning and grading. In case of extensionist out of similar number of available technologies/activities, the highest percent (42.91) was observed in seasonal crops need for drying, cleaning and grading and the lowest percent (29.36) was observed in pests need for drying, cleaning and grading but there is significant variation among three categories of technologies. Similar trends of results also observed for farmers out of same number of available recognized technologies, where the highest percent (23.55) was observed seasonal crops and lowest percent (19.83) was observed in pests need for drying, cleaning and grading. There is no significant difference among three categories of technologies in all categories of respondents. In case of Agribusiness personnel out of similar number of available technologies/activities, the highest percent (80.45) was observed in crop's agribusiness need for drying, cleaning and grading and lowest percent (35.50) as usual was observed in pests need for drying, cleaning and grading but there were significant variations among three categories of technologies. Anonymous (1976)in FAO Production Year Book reported that due to improper harvesting and lack of proper processing and storage and transport facilities, $20-50 \%$ of tomato, $37 \%$ of Cabbage, $49 \%$ of cauliflower and $16-35 \%$ of onion are spoiled and wasted in the developing countries. In regards of the respondents wise distribution of the data shown that the Researcher's marked highest average percent again which is 69.80 and lowest percent results was shown in farmer category as usual where 22.06 -out of average 9.33 technologies respectively followed by agribusiness personnel (63.20) and extensionist (35.63).

\subsection{Storage Environment}

The storage environment comprises the three-major categories viz. Ideas, Perception and Skills of storage environment post harvest technologies/activities. The data were collected on the above three categories for 4 types of 
respondents. The data depicted significant variations in post-harvest storage environment on the NARS recognized technologies regarding four categories of respondent viz. researcher, extensionist, farmer, and agribusiness personnel of crops. In respect of researcher perception about Ideas, out of NARS recognized available technology of $8,10 \& 10$ the percent responses were $91.38,88.80$, and 69.40 where highest percent response perceived under ideas and perception technology and lowest response perceived in skills category of the technology. According to the scientists, the farmers store more than $65 \%$ of the total rice produces till the next season for their food, feed and seed purposes. About 5-8\% of rice was stored for seed [13]. During the storage condition of ambient temperature, rice is being damaged by a number of agents, such as insects, rodents, fungi, mites, birds and moisture [12].

The similar trends also observed for extensionist, farmers and agribusiness personnel, where highest responses were perceived in ideas category of the technology $(80.75,53.00, \& 84.25)$ and lowest in skills category of the technology $(51.50,17.90, \& 53.50)$. Considering the total number of storage environment post-harvest activities/technologies in percent, the maximum technologies (77.34) were perceived in Ideas category of the activities followed by perception (70.02), while the minimum technologies (48.07) in skills category of the technologies. In regards of the respondents wise distribution of the data shown that the Farmer's marked lowest average percent again which is 24.99 and highest percent results was shown in Researcher category as usual where 83.16 out of average $9 . .33$ technologies respectively followed by extensionist (70.32) and agribusiness personnel (70.02). 
Table 5. Perception of pest management based technological knowledge for all categories respondents on pre and post-harvest management of agricultural pests and their economic impacts

\begin{tabular}{|c|c|c|c|c|c|c|c|c|c|c|}
\hline \multirow{3}{*}{$\begin{array}{c}\text { Technological } \\
\text { Category }\end{array}$} & \multicolumn{10}{|c|}{ Categories of Respondents } \\
\hline & \multicolumn{2}{|c|}{ Researcher } & \multicolumn{2}{|c|}{ Extensionist } & \multicolumn{2}{|c|}{ Farmer } & \multicolumn{2}{|c|}{ Agribusiness } & \multicolumn{2}{|c|}{ Total } \\
\hline & $\begin{array}{c}\text { *NARS } \\
\text { Tech (No.) }\end{array}$ & $\begin{array}{c}\text { Response } \\
(\%)\end{array}$ & $\begin{array}{l}\text { *NARS } \\
\text { Tech } \\
\text { (No.) }\end{array}$ & Response (\%) & $\begin{array}{c}\text { *NARS } \\
\text { Tech (No.) }\end{array}$ & $\begin{array}{l}\text { Response } \\
(\%)\end{array}$ & $\begin{array}{c}\text { *NARS } \\
\text { Tech (No.) }\end{array}$ & $\begin{array}{c}\text { Respon } \\
\text { se (\%) }\end{array}$ & $\begin{array}{l}\text { *NARS } \\
\text { Tech } \\
\text { (No.) }\end{array}$ & $\begin{array}{c}\text { Response } \\
(\%)\end{array}$ \\
\hline \multicolumn{11}{|c|}{ 1. Rouging } \\
\hline $\begin{array}{l}\text { Crop(s) need for } \\
\text { rouging }\end{array}$ & 5 & $\begin{array}{l}92.20 \\
(4.61)\end{array}$ & 5 & $\begin{array}{l}62.20 \\
(3.11)\end{array}$ & 5 & $\begin{array}{l}35.00 \\
(1.75)\end{array}$ & 5 & $\begin{array}{l}44.80 \\
(2.24)\end{array}$ & 20 & $\begin{array}{c}58.55 \\
(11.71)\end{array}$ \\
\hline $\begin{array}{l}\text { Pests need for } \\
\text { rouging }\end{array}$ & 7 & $\begin{array}{l}71.14 \\
(4.98)\end{array}$ & 7 & $\begin{array}{l}48.71 \\
(3.41)\end{array}$ & 7 & $\begin{array}{l}23.86 \\
(1.67)\end{array}$ & 7 & $\begin{array}{l}29.00 \\
(2.03)\end{array}$ & 28 & $\begin{array}{c}43.18 \\
(12.09)\end{array}$ \\
\hline $\begin{array}{l}\text { Growth stages of } \\
\text { crops need for } \\
\text { rouging }\end{array}$ & 4 & $\begin{array}{l}94.00 \\
(3.76)\end{array}$ & 4 & $\begin{array}{l}58.25 \\
(2.33)\end{array}$ & 4 & $33.75(1.35)$ & 4 & $\begin{array}{l}56.00 \\
(2.24)\end{array}$ & 16 & $\begin{array}{l}60.50 \\
(9.68)\end{array}$ \\
\hline Average Total & 5.33 & $\begin{array}{l}85.73 \\
(4.45)\end{array}$ & 5.33 & $\begin{array}{c}56.35 \\
((2.95)\end{array}$ & 5.33 & $\begin{array}{c}30.85 \\
((1.59)\end{array}$ & 5.33 & $\begin{array}{l}43.24 \\
(2.17)\end{array}$ & 21.33 & $\begin{array}{c}54.08 \\
(11.16)\end{array}$ \\
\hline \multicolumn{11}{|c|}{ 2. Processing for IPM } \\
\hline $\begin{array}{l}\text { Seasonal crops need } \\
\text { for drying, cleaning } \\
\text { and grading }\end{array}$ & 11 & $\begin{array}{l}73.09 \\
(8.04)\end{array}$ & 11 & $\begin{array}{l}42.91 \\
(4.72)\end{array}$ & 11 & $\begin{array}{l}23.55 \\
(2.59)\end{array}$ & 11 & $\begin{array}{l}73.73 \\
(8.11)\end{array}$ & 44 & $\begin{array}{c}53.32 \\
(23.46)\end{array}$ \\
\hline $\begin{array}{c}\text { Pests need for } \\
\text { drying, cleaning and } \\
\text { grading }\end{array}$ & 6 & $\begin{array}{l}64.83 \\
(3.89)\end{array}$ & 6 & $\begin{array}{l}34.67 \\
(2.08)\end{array}$ & 6 & $\begin{array}{l}19.83 \\
(1.19)\end{array}$ & 6 & $\begin{array}{l}35.50 \\
(2.13)\end{array}$ & 24 & $\begin{array}{l}38.71 \\
(9.29)\end{array}$ \\
\hline $\begin{array}{l}\text { Crop's agribusiness } \\
\text { need for drying, } \\
\text { cleaning and grading }\end{array}$ & 11 & $\begin{array}{l}71.55 \\
(7.87)\end{array}$ & 11 & $\begin{array}{l}29.36 \\
(3.23)\end{array}$ & 11 & $\begin{array}{l}22.82 \\
(2.51)\end{array}$ & 11 & $\begin{array}{l}80.45 \\
(8.85) \\
\end{array}$ & 44 & $\begin{array}{c}51.05 \\
(22.46)\end{array}$ \\
\hline Average Total & 9.33 & $\begin{array}{l}69.80 \\
(6.6) \\
\end{array}$ & 9.33 & $\begin{array}{l}35.63 \\
(3.34)\end{array}$ & 9.33 & $\begin{array}{l}22.06 \\
(2.10)\end{array}$ & 9.33 & $\begin{array}{l}63.20 \\
(6.36) \\
\end{array}$ & 37.33 & $\begin{array}{c}47.69 \\
(18.40) \\
\end{array}$ \\
\hline \multicolumn{11}{|c|}{ 3. Storage Environment } \\
\hline Ideas & 8 & $\begin{array}{l}91.38 \\
(7.31)\end{array}$ & 8 & $\begin{array}{l}80.75 \\
(6.46)\end{array}$ & 8 & $\begin{array}{l}53.00 \\
(4.24)\end{array}$ & 8 & $\begin{array}{l}84.25 \\
(6.74)\end{array}$ & 32 & $\begin{array}{c}77.34 \\
(24.75)\end{array}$ \\
\hline Perception & 10 & $\begin{array}{l}88.80 \\
(8.88)\end{array}$ & 10 & $\begin{array}{l}78.80 \\
(7.88)\end{array}$ & 10 & $\begin{array}{c}4.10 \\
(4.01)\end{array}$ & 10 & $\begin{array}{l}72.40 \\
(7.24)\end{array}$ & 40 & $\begin{array}{c}70.02 \\
(28.01)\end{array}$ \\
\hline Skills & 10 & $\begin{array}{l}69.40 \\
(6.94)\end{array}$ & 10 & $\begin{array}{l}51.50 \\
(5.15)\end{array}$ & 10 & $\begin{array}{l}17.90 \\
(1.79)\end{array}$ & 10 & $\begin{array}{l}53.50 \\
(5.35)\end{array}$ & 40 & $\begin{array}{c}48.07 \\
(19.23)\end{array}$ \\
\hline Average Total & 9.33 & $\begin{array}{l}83.16 \\
(7.71)\end{array}$ & 9.33 & $\begin{array}{l}70.32 \\
(6.50)\end{array}$ & 9.33 & $\begin{array}{l}24.99 \\
(3.35)\end{array}$ & 9.33 & $\begin{array}{l}70.02 \\
(6.44)\end{array}$ & 37.33 & $\begin{array}{l}65.14 \\
(24.0)\end{array}$ \\
\hline
\end{tabular}

The number within the parenthesis indicates the number of technologies being responded by the farmer. ${ }^{*}$ The number of NARS recognized available technologies 


\section{Agribusiness Activities-based Technological Knowledge for all Categories Respondents}

The agribusiness activities consists storage, transportation, and marketing. The data were collected on the above three categories of technological aspects for 4 major crops group and are given in the Table 6.

\subsection{Storage}

The storage consists of major categories termed as Ideas of Post harvest Technology recommended to farmers, perception and skills of post harvest technological problems of farmers and skills of post harvest pest management solutions to farmers. The data were collected on the above three categories of technological aspects for 4 types of respondents and are given in the Table 6.

The results depicted no significant variations in the perceptions of storage activities viz. ideas, perception and skills of crops. In case of researcher the percent of known storage activities ranged from $-64.00-80.20$, where the highest numbers of activities observed in ideas of storage activities with minimal difference with perception and skills. I $\mathrm{n}$ case of extensionist, the highest percent of storage activities (47.90) were observed 5 in Ideas of post harvest technologies but lowest percent (26.63) under skills of post harvest pest management solutions. In respect of farmers, the percent storage activities ranged from 9.13-15.63 where highest percent (15.63) perceived in ideas of post harvest technologies and lowest percent (9.13) perceived in skills of post harvest pest management technologies. The similar trends of results in case of agribusiness where highest percent (81.38) perceived in ideas of post harvest technologies recommended to farmers and the lowest percent (56.38) perceived in skills of Post harvest pest management solution to farmers. Sharp variations were observed among these two categories of respondents. Researcher [16] mentioned that the reason of postharvest loss and damage to grain during storage are: (i) lack of technological knowledge on harvesting; (ii) drying and processing of crops; (iii) grain storage and handling; (iv) grain storage structures and design; (v) prices policies and extension; (vi) insect pests of stored products; and (vii) fungal invasion of stored products.

Considering the total number of ideas about technologies in percent, the maximum technologies (54.08) were perceived by the ideas of post harvest technologies recommended to farmers followed by perception of $\mathrm{PH}$ technological problems to farmers (52.69), while the minimum percent (39.03) in skills of - of post harvest pest management solutions to farmers. The respondents wise distribution of the data shown that the researcher marked highest the average being 72.40 with marginal different with agribusiness person (70.68) and lowest being in case of
Farmer's 12.92 under all three categories out of average 8.67 technologies with significance variation with above two categories including extensionist (38.44).

\subsection{Transportation}

The transportation consists of same three-major categories viz. ideas, perception and skills of transport technologies. The data were collected on the above three categories of post harvest activities for 4 types of respondents. Significant variations were observed in respect of transport technologies in all three categories regarding four categories of respondent's viz. researcher, extensionist, farmer, and agribusiness personnel of crops. In case of researcher, out of $16,8 \& 8$ available recognized activities, the percent of researcher transportation activities about ideas of transport technologies recommended to farmers ranged from 13.13-24.19, where the highest number of activities was observed in respect of ideas and the lowest number of technologies was observed in respect of skills about ideas of transport technologies recommended to farmers. In case of extensionist out of similar number of transport recognized available activities, the highest percent (42.75) was observed in ideas of transport technologies recommended to farmers and the lowest percent (28.88) was observed in skills but there is significant variations among three categories of technologies. Similar trends of results also observed for farmers and agribusiness personnel out of same number of available recognized activities/technologies, where the highest percent 78.81 was observed in ideas and lowest percent 61.88 was observed in skills of transport technologies recommended to farmers. There is significant difference among three categories of technologies in all categories of respondents. FAO Production Year Book reported [2] that due to improper harvesting and lack of proper storage and transport facilities, $20-50 \%$ of tomato, $37 \%$ of Cabbage, $49 \%$ of cauliflower and $16-35 \%$ of onion are spoiled and wasted in the developing countries. Considering the total number of transport technologies recommended to farmers, the maximum technologies (25.13) were perceived in Ideas followed by perception), while the minimum technologies (13.13) in skills of transport technologies recommended to farmers. In regards of the respondents wise distribution of the data shown that the Agribusiness personnel marked highest average percent again which was 72.17 followed by researcher (59.52) and extensionist (35.30), and farmers 20.82 respectively.

\subsection{Marketing}

The marketing technology comprises Ideas, Perception and Skills of marketing technologies recommended to farmers. The data were collected on the above three categories for 4 types of respondents. The data depicted minimal variations in marketing on the NARS recognized 
technologies recommended to farmers regarding four categories of respondent viz. researcher, extensionist, farmer, and agribusiness personnel of crops. In respect of researcher ideas about marketing technological knowledge, out of NARS recognized available technology of $20,8 \& 8$, the percent responses were $45.65,58.63$, and 43.00 where highest percent response perceived under perception of marketing problems of the farmers and lowest response perceived in skills of marketing problems solutions to the farmers.

The similar trends also observed for extensionist, and agribusiness personnel, where highest responses were perceived in perception of marketing problems of the Agribusiness 81.50 and lowest in skills of marketing problems solutions category of the technology 16.25 . In case of skills of marketing problems solution, highest responses were perceived in Agribusiness (52.50) and s lowest percent response perceived in farmers cases 11.63 respectively. Ahmed [1] mentioned that traditional post-harvest handling and marketing system of HVCs is one of the major hindrances for the increased production and utilization of HVCs in the northwest region of the country. The major constraints identified relating to general awareness may be summarized as inadequate knowledge on harvesting, post-harvest handling, storage and transportation; in-sufficient knowledge and skills in adhering to the use of recommended/approved pesticides; lack of awareness on the quality and environmental issues; and in adequate knowledge and poor packaging of perishables.

Considering the total number of marketing activities/technologies in percent, the maximum technologies (17.35) were perceived in Ideas of marketing technologies recommended to farmers followed by Perception of marketing problems 16.25 and Skills of marketing problems 11.63 respectively to the farmers .In regards of the respondents wise distribution of the data shown that the Farmer's marked lowest average percent again which is 15.08 and highest percent results was shown in Agribusiness personnel where 63.33 out of average 12 technologies respectively followed by researcher (49.09) and extensionist (29.84). 
Table 6. Perception of Agribusiness activities based technological knowledge for all categories respondents on pre and post harvest (PH) management of agricultural pests and their economic impacts.

\begin{tabular}{|c|c|c|c|c|c|c|c|c|c|c|}
\hline \multirow{3}{*}{ Technological Category } & \multicolumn{10}{|c|}{ Categories of Respondents } \\
\hline & \multicolumn{2}{|c|}{ Researcher } & \multicolumn{2}{|c|}{ Extensionist } & \multicolumn{2}{|c|}{ Farmer } & \multicolumn{2}{|c|}{ Agribusiness } & \multicolumn{2}{|c|}{ Total } \\
\hline & $\begin{array}{l}\text { *NARS } \\
\text { Tech } \\
\text { (No.) }\end{array}$ & $\begin{array}{l}\text { Response } \\
(\%)\end{array}$ & $\begin{array}{c}\text { *NARS } \\
\text { Tech (No.) }\end{array}$ & $\begin{array}{c}\text { Response } \\
(\%)\end{array}$ & $\begin{array}{l}\text { *NARS } \\
\text { Tech } \\
\text { (No.) }\end{array}$ & Response (\%) & $\begin{array}{l}\text { *NAR } \\
\text { S Tech } \\
\text { (No.) }\end{array}$ & Response (\%) & $\begin{array}{l}\text { *NAR } \\
\text { S Tech } \\
\text { (No.) }\end{array}$ & Response (\%) \\
\hline \multicolumn{11}{|l|}{ 1. Storage } \\
\hline $\begin{array}{l}\text { Ideas of PH technologies } \\
\text { recommended to farmers }\end{array}$ & 10 & $\begin{array}{l}80.20 \\
(8.02)\end{array}$ & 10 & $\begin{array}{l}47.90 \\
(4.79)\end{array}$ & 10 & $\begin{array}{l}14.00 \\
(1.40)\end{array}$ & 10 & $\begin{array}{l}74.20 \\
(7.42) \\
\end{array}$ & 40 & $\begin{array}{c}54.08 \\
(21.63)\end{array}$ \\
\hline $\begin{array}{l}\text { Perception of PH } \\
\text { technological problems of } \\
\text { farmers }\end{array}$ & 8 & $\begin{array}{l}73.00 \\
(5.84)\end{array}$ & 8 & $\begin{array}{l}40.75 \\
(3.26)\end{array}$ & 8 & $\begin{array}{l}15.63 \\
(1.25)\end{array}$ & 8 & $\begin{array}{l}81.38 \\
(6.51)\end{array}$ & 32 & $\begin{array}{c}52.69 \\
(16.86)\end{array}$ \\
\hline $\begin{array}{l}\text { Skills of PH pest } \\
\text { management solutions to } \\
\text { farmers }\end{array}$ & 8 & $\begin{array}{l}64.00 \\
(5.12)\end{array}$ & 8 & $\begin{array}{l}26.63 \\
(2.13)\end{array}$ & 8 & $\begin{array}{c}9.13 \\
(0.73)\end{array}$ & 8 & $\begin{array}{l}56.38 \\
(4.51)\end{array}$ & 32 & $\begin{array}{c}39.03 \\
(12.49)\end{array}$ \\
\hline Average Total & 8.67 & $\begin{array}{l}72.40 \\
(6.33)\end{array}$ & 8.67 & $\begin{array}{l}38.44 \\
(3.39)\end{array}$ & 8.67 & $\begin{array}{l}12.92 \\
(1.13)\end{array}$ & 8.67 & $\begin{array}{l}70.68 \\
(6.15) \\
\end{array}$ & 34.66 & $\begin{array}{c}48.6 \\
(16.99)\end{array}$ \\
\hline \multicolumn{11}{|l|}{ 2. Transportation } \\
\hline $\begin{array}{c}\text { Ideas of transport } \\
\text { technologies recommended } \\
\text { to farmers }\end{array}$ & 16 & $\begin{array}{c}64.00 \\
(10.24)\end{array}$ & 16 & $\begin{array}{l}42.75 \\
(6.84)\end{array}$ & 16 & $\begin{array}{l}24.19 \\
(3.87)\end{array}$ & 16 & $\begin{array}{c}78.81 \\
(12.61)\end{array}$ & 64 & $\begin{array}{c}52.44 \\
(33.56)\end{array}$ \\
\hline $\begin{array}{l}\text { Perception of transport } \\
\text { problems of farmers }\end{array}$ & 8 & $\begin{array}{l}64.25 \\
(5.14)\end{array}$ & 8 & $\begin{array}{l}34.25 \\
(2.74)\end{array}$ & 8 & $\begin{array}{l}25.13 \\
(2.01)\end{array}$ & 8 & $\begin{array}{l}75.75 \\
(6.06)\end{array}$ & 32 & $\begin{array}{c}49.84 \\
(15.95)\end{array}$ \\
\hline $\begin{array}{l}\text { Skills of transport } \\
\text { technological solutions to } \\
\text { farmers }\end{array}$ & 8 & $\begin{array}{l}50.25 \\
(4.02)\end{array}$ & 8 & $\begin{array}{l}28.88 \\
(2.31)\end{array}$ & 8 & $\begin{array}{l}13.13 \\
(1.05)\end{array}$ & 8 & $\begin{array}{l}61.88 \\
(4.95) \\
\end{array}$ & 32 & $\begin{array}{c}38.53 \\
(12.33)\end{array}$ \\
\hline Average Total & 10.67 & $\begin{array}{l}\mathbf{5 9 . 5 2} \\
(6.47) \\
\end{array}$ & 10.67 & $\begin{array}{l}\mathbf{3 5 . 3 0} \\
(3.96)\end{array}$ & 10.67 & $\begin{array}{l}20.82 \\
(2.31)\end{array}$ & 10.67 & $\begin{array}{l}72.17 \\
(7.87)\end{array}$ & 42.66 & $\begin{array}{c}44.94 \\
(20.61)\end{array}$ \\
\hline \multicolumn{11}{|l|}{ 3. Marketing } \\
\hline $\begin{array}{c}\text { Ideas of marketing } \\
\text { technologies recommended } \\
\text { to farmers }\end{array}$ & 20 & $\begin{array}{l}45.65 \\
(9.13)\end{array}$ & 20 & $\begin{array}{l}33.40 \\
(6.68)\end{array}$ & 20 & $17.35(3.47)$ & 20 & $\begin{array}{c}56.00 \\
(11.20)\end{array}$ & 80 & $\begin{array}{c}38.10 \\
(30.48)\end{array}$ \\
\hline $\begin{array}{l}\text { Perception of marketing } \\
\text { problems of the farmers }\end{array}$ & 8 & $\begin{array}{l}58.63 \\
(4.69) \\
\end{array}$ & 8 & $\begin{array}{l}34.63 \\
(2.77) \\
\end{array}$ & 8 & $16.25(1.30)$ & 8 & $\begin{array}{l}81.50 \\
(6.52) \\
\end{array}$ & 32 & $\begin{array}{c}47.75 \\
(15.28) \\
\end{array}$ \\
\hline $\begin{array}{l}\text { Skills of marketing } \\
\text { problems solutions to the } \\
\text { farmers }\end{array}$ & 8 & $\begin{array}{l}43.00 \\
(3.44)\end{array}$ & 8 & $\begin{array}{l}21.50 \\
(1.72)\end{array}$ & 8 & $11.63(0.93)$ & 8 & $\begin{array}{l}52.50 \\
(4.21) \\
\end{array}$ & 32 & $\begin{array}{c}32.16 \\
(10.30) \\
\end{array}$ \\
\hline Average Total & 12 & $\begin{array}{l}49.09 \\
(5.75)\end{array}$ & 12 & $\begin{array}{l}29.84 \\
(3.72)\end{array}$ & 12 & $15.08(1.9)$ & 12 & $\begin{array}{l}63.33 \\
(7.31) \\
\end{array}$ & 48 & $\begin{array}{c}39.34 \\
(2135)\end{array}$ \\
\hline
\end{tabular}

The number within the parenthesis indicates the number of technologies being responded by the farmer. the number of NARS recognized available technologies 


\section{Conclusions}

There are about more than 300 NARS recommended technologies for agricultural sector including pre- and post-harvest agricultural pest management system in Bangladesh, but only a few of them are being practiced at the field level. There is a big knowledge gap among researchers and other respondent. Considering pest management agribusiness activities based all technological aspects, perception of researchers on NARS Technological Knowledge found much higher than farmers, extensionists and agribusiness personnel. Most of the respondents are very much aware about the rice based technologies than other crops. Especially most of the small scale poor farmers are interested to use cheap, easy handling and locally available technology for their crop pest management in storage and field. To get maximum output from any crop resources at field level need to be focused on strengthening the linkage and co-ordination among researchers, educationists and extensionists. Web-based detailed technological information should be available for wider dissemination.

\section{REFERENCES}

[1] Ahmed, MS. 2003. Interim Report from 15 September to 15 December 2003 as National Consultant for Post-Harvest and Agribusiness Specialist for Northwest Crop Diversification Project, Department of Agricultural Extension (DAE), Khamarbari, Dhaka, Bangladesh. 15p.

[2] Anonymous. 1976. FAO Production Year. Vol. 30.Food and Agriculture Organization of the United Nations. Roam, Italy.

[3] BBS (Bangladesh Bureau of Statistics). 2007. Department of Agricultural Extension Agricultural Statistical of Bangladesh. Bangladesh Bureau of Statistics, Planning Division, Ministry of Planning, Government of the people's republic of Bangladesh, Dhaka. 514 pp.

[4] BCSIR. 1991. Report of SAAIC joint project on appropriate post-harvest technology for perishable food items such as fish, fruits and vegetables. SAIC, SAARC, Farmgate, Dhaka, Bangladesh.

[5] Damalas, C.A., Eleftherohorinos, I.G. 2011. Pesticide exposure, safety issues, and risk assessment indicators.
International Journal of Environmental Research and Public Health, 8: 1402-19.

[6] Goletti, F. and Wolff, C. 1999.The impact of postharvest research.Market and Structural Studies Division, International Food Policy Research Institute, USA.

[7] Hartulistiyoso, E., Rusli, M.S., and Lucke, W. 1998: Post harvest technology and processing of spices in Indonesia. Institut fur Agrartechnik, Universitat Gottingen, Gutenbergerstrasse 33, D-37075 Gottingen, Germany. Landtechnik. 53(4): 252-253.

[8] Hoque, A. 2004.Agribusiness a promising sector for our economy. The Daily Bangladesh Observer, Published on January 16, 2004.

[9] Karim, A.N.M.R., 1986. The Hispa Episode. A paper presented at the $12^{\text {th }}$ Workshop on Modern Rice Cultivation in Bangladesh" Jointly sponsored by Bangladesh Rice research Institute and Department of Agriculture Extension, 5-7 April, BRRI, Joydebpur, Gazipur. 33pp.

[10] Maini, S.B. 1997: Present status and future prospects of post-harvest technology of vegetables. Division of Fruits and Horticultural Technology, Indian Agricultural Research Institute, New Delhi-110012, India.Agricultural-Marketing. 40(3): 21-24.

[11] Manjunatha, BN.,Lakshminarayan,MT., and Anand, TN. 1998. Variables influencing farmers' aspirations for new post-harvest technologies in groundnut, Current-Research, University of Agricultural Sciences Bangalore. Pp 184-185

[12] Prakas, A, and J. Rao. 1983. Insect pests and their management in rice storage in India, presented in National Symposium on Maximizing and Stabilizing of yields on rain fed rice production system held at CSRRI, Cuttack (India) on Feb. 23-25, 1983.

[13] Prakash, A, J. Rao, I. C. Pasalu and K. C. Mathur. 1987. Rice Storage and insect pest management. B. R. Publishing Corporation. Delhi, pp.15-60.

[14] Rahman S. 2013. Pesticide consumption and productivity and the potential of IPM in Bangladesh. Science of the Total Environment, 445-446, 48-56.

[15] Ross, S. 1998. Farmers' perceptions of bean pest problems in Malawi.Bean Improvement Project, Chitedze Agricultural Research Station, P.O. Box 158, Lilongwe, Malawi.CIAT-African-Occasional-Publications-Series.199 8 , No. 25, 31p.

[16] Wongo, L.E. 1997. Review of Kenyan agricultural research: Vol. 11 Post-harvest technology. Jomo Kenyatta University, Nairobi, Kenya.PP 30 